\title{
部材の途中まで鉄骨が存在するコンクリート系複合部材の終局耐力 ULTIMATE STRENGTH OF MIXED MEMBER WITH REINFORCED CONCRETE AND STEEL PARTIALLY EXISTING IN THE SPAN
}

\author{
鈴木英之*, 西原 寛**, 松崎育弘*** \\ Hideyuki SUZUKI, Hiroshi NISHIHARA and Yasuhiro MATSUZAKI
}

\begin{abstract}
This paper discusses about the method of evaluation for strength of the member which composed of SRC at one side or both sides and RC in other section. The experiment of column where steel existed on the way of the height of column was carried out. As a result, the shear strength of the columns with the internal steel was lower than that of column without steel. Regard to such member, the methods of calculation for the flexural strength and the shear strength were proposed. Therefore it became to possible to evaluation for ultimate strength correspond with the destruction type.
\end{abstract}

Keywords : reinforced concrete, steel reinforced concrete, mixed structure, shear strength, flexural strength 鉄筋コンクリート，鉄骨鉄筋コンクリート，複合構造，せ九断終局耐力，曲げ終局耐力

\section{1. はじめに}

筆者らは，部材の途中まで鉄骨が存在するコンクリート系複合部 材に着目し，部材の途中で切断されている鉄骨と周囲の鉄筋コンク リート(以下RC)部分の相互関係について一連の研究を実施してきた 2) 4)。その中で，材端部が鉄骨鉄筋コンクリート(以下SRC)造，中 央部がRC造で構成される複合構造梁の実験結果より, 鉄骨が材軸 方向で不連続な状態でも鉄骨に定着治具を設けることによって材端 部のSRC断面において一般化累加強度を超える曲代終局耐力を発揮 すること2)を明らかにした。また，柱脚部がSRC造，柱頭部がRC造 で構成される柱部材を想定し，柱脚部から延びる鉄骨の長さを変動 要因とした実験の結果より，部材の途中まで存在する鉄骨によって 部材のせん断抵抗機構が変化し，鉄骨の長さによって鉄骨が無い $\mathrm{RC}$ 造区間のせん断終局耐力が変化寸ること3)を明らかにした。さら に， RC部分から鉄骨への応力伝達機構を想定し， RC部分に形成さ れるアーチ機構に伴うコンクリート圧縮束が鉄骨の切断位置付近で 折れ曲がるモデルを提案した4)。それまでに部材の途中まで鉄骨が 存在する部材のせん断耐力の評価に関寸る研究法皆無であったが, 筆者らは同文献において, 内蔵された鉄骨によってRC部分のせん 断終局耐力が增加する要因と低下寸る要因があることを指摘し，そ のせん断抵抗機構に基づいた RC部分のせん断終局耐力の評価方法
を提案した。

図1に本論で対象とする部材の例示す。このような部材は梁抢 よび柱の両方で使用されることが考えられ，片側の端部にだけ鉄骨 が存在する場合と両側に存在する場合がある。このように形状や応
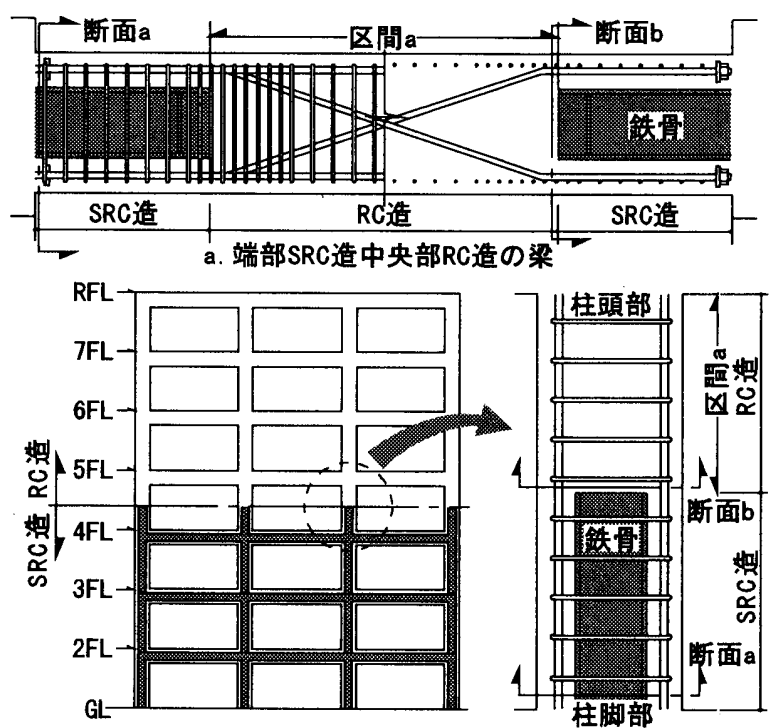

b. 柱脚部SRC造柱頭部RC造の柱

図1本論で対象とする部材の例
本論文の一部は参考文献1)にて発表している。

$*$ 安藤建設( 侏技術研究所 博士 (工学)

**安藤建設(侏技術研究所

*** 東京理科大学工学部建築学科 教授. 工博
Ando Corporation Research Center, Dr. Eng.

Ando Corporation Research Center

Prof., Dept. of Architecture, Faculty of Engineering, Science Univ. of Tokyo, Dr. Eng. 
力状態が異なる部材に対して，統括的な耐力の評価法を確立するこ 上は，今後多様化すると考えられる構造形式の複合化に対して，不 可欠である。

図1に示す部材において，曲げモーメントが存在する位置で鉄骨 が切断されている場合は，その鉄骨に代わって曲げ応力を負担する ための曲げ補強筋が必要となる。鉄骨鉄筋コンクめート造配筋指針 (案) ・同解説5) (以下SRC造配筋指針案)によると, 鉄骨が切断され ている位置近傍に生じる曲げモーメントに対する断面の曲げ耐力の 割合(以下，曲代補強率)を110\%程度とすれば強度的には十分である とされている。また，同様な切り替え部の補強に関する研究として， 文献6)では材端部の曲げ終局耐力時に切り替え部の曲げ補強率を $120 \%$ ，文献7)では同じく $140 \%$ とすることで安定した履歷性能が得 られると報告されている。これらの数値は，いずれも実験結果から 導かれたものであり，理論的な裏付けが不十分である。

SRC造からRC造へ構造形式が切り替わる柱部材を対象とした既 往の研究としては，木村らが，試験区間に埋め込まれる鉄骨の長さ を変化させた実験を行っており8)，鉄骨の埋め込み長さによって SRC断面の曲げ耐力が単純累加強度と一般化累加強度の間で変化す ると報告している。また，西村らは，曲げ破壊が先行する柱試験体 において，内蔵される鉄骨の長さ，鉄骨断面および帯筋比を変動要 因とした実験を行っているが9)，断面の曲げ耐力やせん断耐力に関 する検討はされていない。

本論では，部材の途中まで鉄骨が存在するコンクリート采部材に 関する既報2) 4)の実験結果と，新たに実施した柱脚部SRC造柱頭 部RC造柱の実験結果を基に，それぞれの破壊性状に対応した終局 耐力を統括的に評価する手法を提案する。せん断終局耐力に関して は既報4)で提案しているが，一般的な部材の評価には式の構成が複
雑であった。そこで，本論では鉄骨が途中まで存在寸るコンクリー 卜系部材のせ九断終局耐力を，より一般的な形で評価するために， いくつかの条件を簡略化した実用せん断終局耐力式を提案寸る。

また，併せて部材の途中で不連続となっている鉄骨を含んだSRC 断面の曲げ終局耐力，および鉄骨が切断されている断面の曲代終局 耐力の評価法を示す。つまり，本論では図1中の区間a知し断終局 耐力，および断面 a,bにおける曲げ終局耐力の評価法を提案する。 SRC造の区間のせん断終局耐力，および主筋の付着割裂強度等は従 来の計算法によって評価できるとして本論では言及しない。

\section{2. 部材の途中まで鉄骨が存在する部材の構造実験 2.1 試験体}

表 1 に端部 $S R C$ 造中央部 $R C$ 造梁実験, 表 2 に柱脚部 SRC造柱頭部 $\mathrm{RC}$ 造の柱実験の試験体一覧，また図2にこれらの試験体の形状図の 一例を示す。このうち，試験体No.1〜8については既報2)に，試験 体No.9〜12については既報3)および4)にて実験結果を報告している。 端部SRC造中央部RC造の梁の実験では，主に部材の曲げ降伏が 先行する試験体を用いてその構造性能を報告した。梁試験体に与え た主な変動要因は，鉄骨が切断されている箅所の曲代補強筋として 配された添え筋の形状とその定着方法, 鉄骨のスタッドコネクタの 有無, 肋筋比, および試験体の断面形状とした。

一方，表2に示した試験体は建物の中間階で構造形式がSRC造か らRC造へと切り替わる階の柱を想定している。このうち，No.9〜 16はRC造区間のせん断破壊が先行するように計画された試験体で あり，No.9〜12は，柱脚部から延びる鉄骨の長さを変動要因とし， 内藏される鉄骨の長さが部材のせん断耐力に与える影響を調べた。 No.13〜16は定着される鉄骨の長さを，す心゙て柱の内法スパン長の

表1試験体およひ実験結果一覧(端部SRC中央RC梁実験)

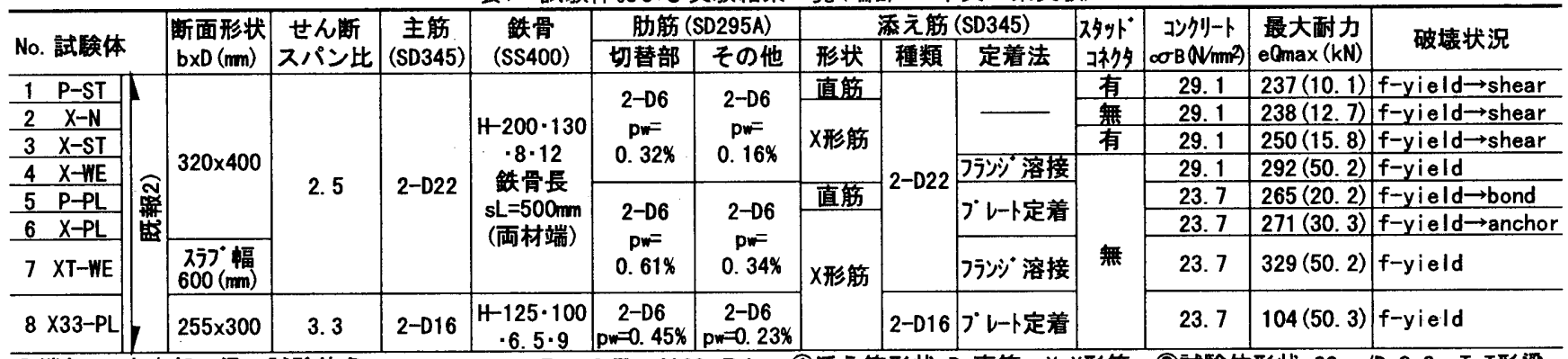

O端部SRC中央部RC梁の試験体名 $\quad P-S T \quad X 33-P L$ (1)添元筋形状 $P:$ 直筋、 $X: X$ 形筋 (3)試験体形状 $33: a / D=3.3 \quad T: T$ 形梁

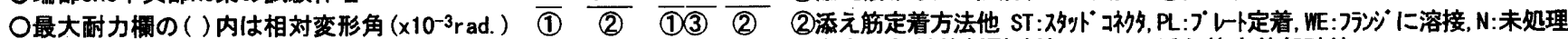

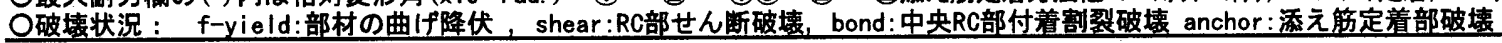

表2 試験体および実験結果一覧(柱脚部SRC柱頭部RC柱実験)

\begin{tabular}{|c|c|c|c|c|c|c|c|c|c|c|c|c|c|}
\hline \multirow{2}{*}{\multicolumn{2}{|c|}{ No. 試験体 }} & \multicolumn{2}{|c|}{ 柱湖側 } & \multicolumn{2}{|c|}{ 柱頭側 } & \multicolumn{3}{|c|}{ 鉃骨 (SS400) } & \multirow{2}{*}{$\begin{array}{c}\text { 軸力 } \\
\text { 比 }\end{array}$} & \multirow{2}{*}{ 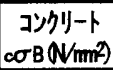 } & \multirow{2}{*}{$\begin{array}{l}\text { 最大酎力 } \\
\text { eOmax (kN) }\end{array}$} & \multirow{2}{*}{ 破棲状況 } & \multirow{2}{*}{ 備考 } \\
\hline & & 主筋 & 蒂筋 & 主筋 & 带㳙 & 種類 & 定著長 & 定苜金物 & & & & & \\
\hline $983-00$ & \multirow{11}{*}{ के } & \multirow{5}{*}{$\begin{array}{l}8-D 19 \\
\text { (SD685) } \\
\text { PE0 } \\
=1.44 \%\end{array}$} & \multirow{5}{*}{$\begin{array}{l}2-D 10 \\
(S D 295 A) \\
\text { pwo } \\
=0.30 \%\end{array}$} & \multirow{5}{*}{$\begin{array}{l}\text { 8-D19 } \\
\text { (SD685) } \\
\text { pg1 } \\
=1.44 \%\end{array}$} & \multirow{5}{*}{$\begin{array}{l}2-D 10 \\
(S D 295 A) \\
p w 1 \\
=0.30 \%\end{array}$} & \multirow{8}{*}{$\mid \begin{array}{c}H 200-204 \\
\cdot 12 \cdot 12\end{array}$} & $0(\mathrm{~mm})$ & & \multirow{9}{*}{0.15} & 25.9 & $431(9.3)$ & sh & \multirow{11}{*}{ 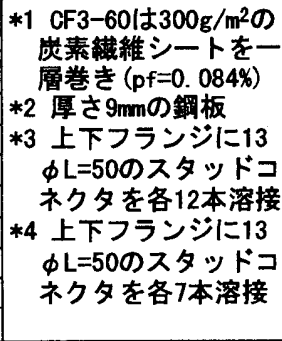 } \\
\hline $10 \$ 3-30$ & & & & & & & 300 & & & 25.9 & $401(6.1)$ & & \\
\hline $11 s 3-60$ & & & & & & & 600 & & & 25.9 & $400(8.4)$ & shear & \\
\hline 12 s3-90 & & & & & & & 900 & & & 25.9 & $446(9.7)$ & ar & \\
\hline 13 CF $3-60^{* 1}$ & & & & & & & 600 & & & 27.1 & $673(32.2)$ & sh & \\
\hline $14 \mathrm{~T} 3-\mathrm{PL}$ & & \multirow{3}{*}{$\begin{array}{l}4-D 19 \\
\text { (SD685) } \\
\mathrm{Pg}_{0} \\
=0.72 \%\end{array}$} & \multirow{3}{*}{$\begin{array}{l}2-D 10 \\
(S D 295 A) \\
\text { Pw0 } \\
=0.30 \%\end{array}$} & \multirow{3}{*}{$\begin{array}{l}8-D 19 \\
(\text { SD685) } \\
\text { Pg1 } \\
=1.44 \% \\
\end{array}$} & \multirow{3}{*}{$\begin{array}{l}p_{w 1}=0.3 \% \\
p_{w 1}=0.6 \% \\
p_{w 1}=0.6 \% \\
\end{array}$} & & \multirow{6}{*}{600} & スモZナ*2 & & 26.0 & $384(8.3)$ & she & \\
\hline 15 T6-PL & & & & & & & & スチフナ & & 26.0 & $0.1)$ & shear & \\
\hline 16 T6-SD & & & & & & & & Zצット์ $A^{* 3}$ & & 26.0 & $(9.8)$ & shear & \\
\hline $17 \mathrm{M6}-\mathrm{PL}$ & & 4-D19 & 2-D10 & 8-D19 & $2-D$ & & & スチフナ & & 26.0 & $448(18.8)$ & f-yield- & \\
\hline 18 M6-PLO & & (SD345) & $(\mathrm{SD} 295 \mathrm{~A})$ & (SD345) & (SD2 & 100 & & スチフ十 & \multirow[b]{2}{*}{0} & 26.0 & $309(20.1)$ & $f-y i e$ & \\
\hline $19 \mathrm{M6}$-SDO & & $\stackrel{p g 0}{=0.72 \%}$ & $\stackrel{p=0}{=0.30 \%}$ & $\stackrel{\mathrm{pg}}{=1.44 \%}$ & $\stackrel{p}{=} 0.1$ & & & スタッドB*4 & & 26.0 & $311(20.0)$ & f-yield & \\
\hline
\end{tabular}

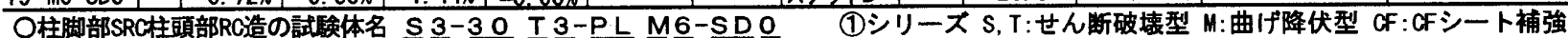

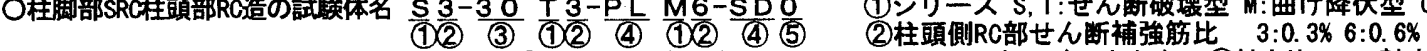

(3)試験区間に埋め込まれた鉄骨長 $(\mathrm{cm})$ (4)鉄骨の定着方式 PL:スチフナ SD:スタッドコネクタ (5)靓力比 $0:$ 軸力無し 無印:0.15 

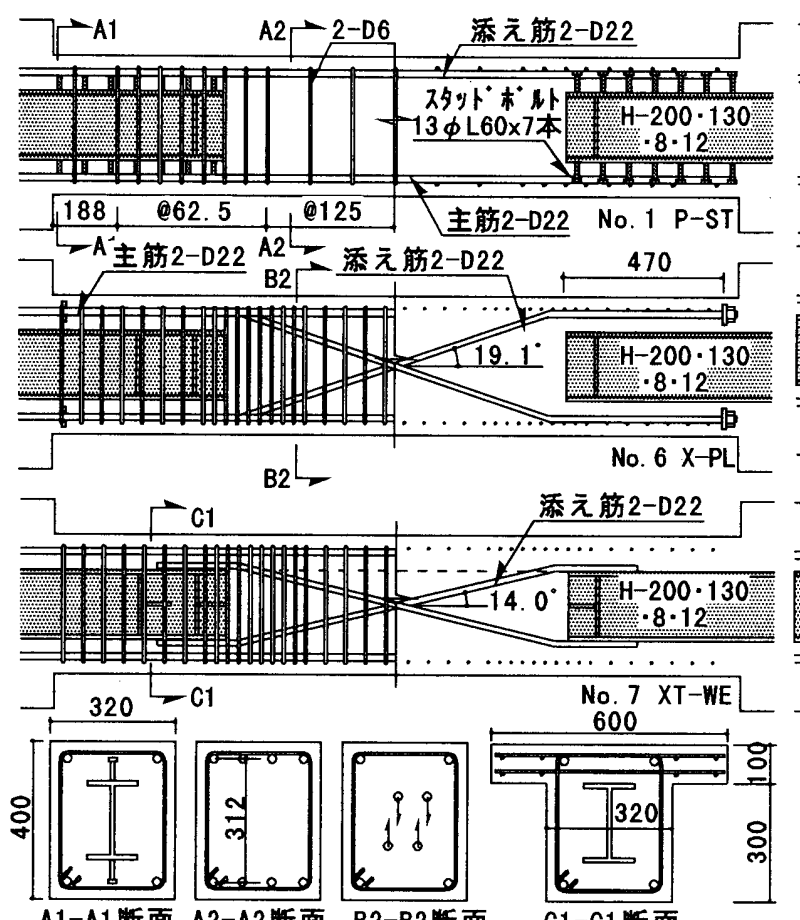

A2-A2断面 B2-B2断面

表3 鉄筋，鉄骨および炭素織維シートの材料試験結果

\begin{tabular}{|c|c|c|c|c|c|c|c|}
\hline & 種類 & \multicolumn{2}{|c|}{ 試験体No. } & \multicolumn{2}{|c|}{ 使用簓所 } & $y\left(N / m^{2}\right)$ & $(\mathrm{kN} /$ \\
\hline 端 & D22A & \multicolumn{2}{|c|}{ No. 4} & \multicolumn{2}{|c|}{ 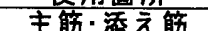 } & 393 & 196 \\
\hline 部 & D22B & \multicolumn{2}{|c|}{ No. 1 3,5 7 } & \multicolumn{2}{|c|}{ 主管・添え飭 } & & \\
\hline & D16 & \multicolumn{2}{|c|}{ No. 8} & \multicolumn{2}{|c|}{ 主筋·添え筋 } & 35 & 103 \\
\hline a & PL12A & \multicolumn{2}{|c|}{ Vo. $1 \sim 4$} & \multicolumn{2}{|c|}{$\mathrm{H}-200 \cdot 130 \cdot 8 \cdot 12$} & & \\
\hline 央 & PL12B & \multicolumn{2}{|c|}{ No. $5 \sim 7$} & \multicolumn{2}{|c|}{$\mathrm{H}-200 \cdot 130 \cdot 8 \cdot 12$} & & \\
\hline \multirow{3}{*}{ 梁 } & PL9 & \multicolumn{2}{|c|}{ No. 8} & \multicolumn{2}{|c|}{$\mathrm{H}-125 \cdot 100 \cdot 6.5 \cdot 9$} & & 20 \\
\hline & D6 & No. 1 & $\sim 8$ & 肋触 & ・スラブ能 & 43 & 1 \\
\hline & \multicolumn{2}{|c|}{ 種類 } & \multicolumn{2}{|c|}{ 試験体No. } & 使用筬所 & $\left.n^{2}\right)$ & 5 \\
\hline \multirow{3}{*}{ 柱 } & D19A & D685) & \multirow{2}{*}{\multicolumn{2}{|c|}{ No. $13 \sim 16$}} & 主筋 & 75 & \\
\hline & \multicolumn{2}{|c|}{$D 19 B(S D 345)$} & & & 主筋 & & \\
\hline & \multicolumn{2}{|c|}{ D10 } & \multicolumn{2}{|c|}{$N_{0} 13 \sim 10$} & 带能 & 36 & \\
\hline \multirow{3}{*}{$\begin{array}{l}\text { SRC } \\
\text { 祽 } \\
\text { RC } \\
\text { 柱 }\end{array}$} & \multicolumn{2}{|c|}{ PL12 } & \multicolumn{2}{|c|}{ No. $13 \sim 16$} & $\mathrm{H}-200 \cdot 204$ & 228 & 209 \\
\hline & \multicolumn{2}{|c|}{ PL8 } & \multicolumn{2}{|c|}{ No. $17 \sim 19$} & $\mathrm{H}-200 \cdot 100$ & 30 & 20 \\
\hline & \multicolumn{2}{|c|}{ CFシート } & \multicolumn{2}{|c|}{ No. 13} & 外周補強 & $287 * 2 * 3$ & $209 * 3$ \\
\hline \multicolumn{8}{|c|}{ 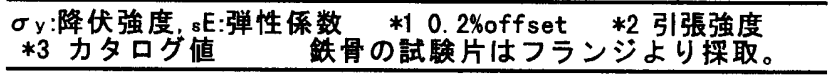 } \\
\hline
\end{tabular}

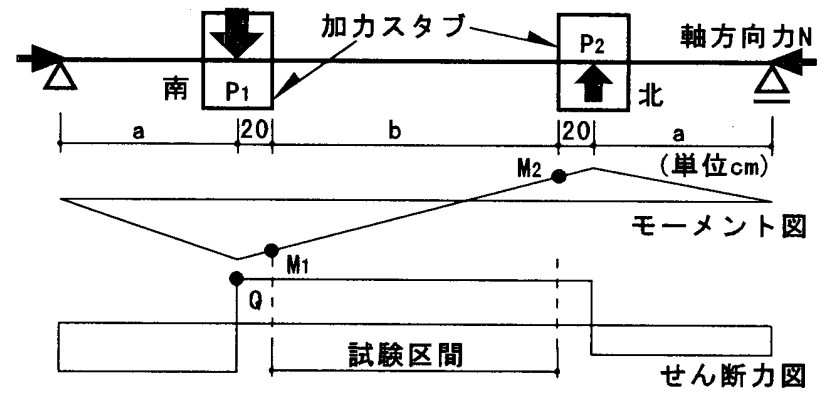

試験体の寸法，モーメント，せん断力の関係 ( $\mathrm{R}$ :層間変形角)

\begin{tabular}{c|c|c|l|l|l}
\hline$(\mathrm{cm}) \mathrm{a}$ & $\mathrm{b}$ & \multicolumn{1}{c}{$\mathrm{M}_{1}$} & \multicolumn{1}{c}{$\mathrm{M}_{2}$} & \multicolumn{1}{c}{0} \\
\hline 梁 & 125 & 200 & $-88 \mathrm{P}_{1}+37 \mathrm{P}_{2}$ & $37 \mathrm{P}_{1}-88 \mathrm{P}_{2}$ & $-0.255\left(\mathrm{P}_{1}+\mathrm{P}_{2}\right)$ \\
柱 & 80 & 120 & $-55 \mathrm{P}_{1}+25 \mathrm{P}_{2}+60 \mathrm{~N} \cdot \mathrm{R}$ & $25 \mathrm{P}_{1}-55 \mathrm{P}_{2}+6 \mathrm{ON} \cdot \mathrm{R}$ & $-0.25\left(\mathrm{P}_{1}+\mathrm{P}_{2}\right)+\mathrm{N} \cdot \mathrm{R}$ \\
\hline
\end{tabular}
図3 加力図

1/2である600mmとし，せん断補強量および鉄骨の定着形式がせん 断耐力に与える影響を調べた。No.14〜19は，柱断面の四隅の主筋 は柱頭から柱脚まで通じているが，それ以外の主筋は柱頭から延び てきて柱脚側の材端部の手前でプレート定着した。つまり柱頭部で 曲げ耐力に寄与する主筋は8-D19であるのに対し，柱脚部は4-D19

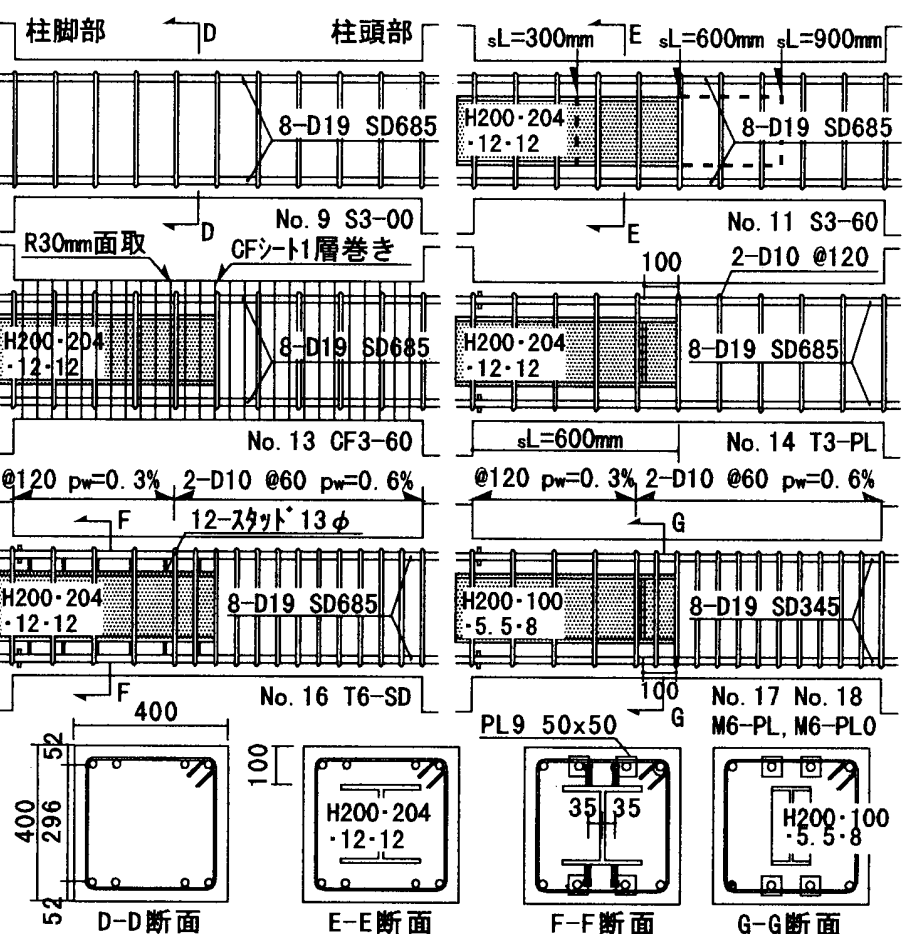

試験体形状図

である。ここで，試験体名に「PL」が付くものは鉄骨にスチフナ，

「SD」が付くものはフランジにスタッドコネクタを設けた。

No.17〜19は, 曲代降伏先行型試験体であり, No.18と19は軸力比 が0である。これらの試験体は反曲点がスパン中央よりも若干柱頭 側に位置するが，降伏ヒンジは両材端部に形成されるように計画し た。CF3-60 こT3-PLは試験区間全長に渡って帯筋比 $\left(p_{w}\right)$ を0.3\%とし， 他のNo.15〜19はRC造の区間のみ $p=0.6 \%$ とした。CF3-60はNo.11の S3-60 鉄骨および配筋が同じ試験体を炭素緎維シート(以下CFシー ト)でせん断補強した試験体であり，目付量が $300 \mathrm{~g} / \mathrm{m}^{2}$ のCFシートを 試験区間全体に一層巻きした。

表3に使用材料の試験結果を示す。なお，各試験体のコンクリー 卜圧縮強度 $(c \sigma B)$ は表1および表2中に示した。

図3に加力図を示寸。柱試験体のNo.9〜No.17は軸力比を 0.15 とし, 他の試験体は軸力比を 0 とした。加力は, 所定の軸方向応力度老保 持させた状態で，試験区間の両側の加力スタブに取り付けた押し引 き油圧ジャッキによって，左右の加力スタブの絶対変位量が逆対称 となるように制御し，正負交番繰り返し載荷とした。

\section{2 実験結果}

本論では部材の終局耐力に主眼をおいているため,ここでは主に， 破壊性状と終局耐力について報告する。また, 試験体No.1〜 12の実 験結果についての詳細は既報2)４）を参照されたい。

\section{2.1 端部 $S R C$ 造中央部 $R C$ 造梁}

No.1〜8の実験結果より, 中央RC部分に配する添え筋をX形筋と し，その鉄筋端部をSRC造区間へ確実に定着寸ることによって，材 端部において一般化累加強度を上回る曲代耐力を発揮し，大変形時 まで安定した履歴性状が得られることが確認された。一方で, 添え 筋の定着が不完全だった試験体, および添え筋を平行配筋とした試 験体は，部材の曲げ降伏後にRC造区間のせ九断破壊，または付着 割裂破壊が発生し，耐力が低下した。 

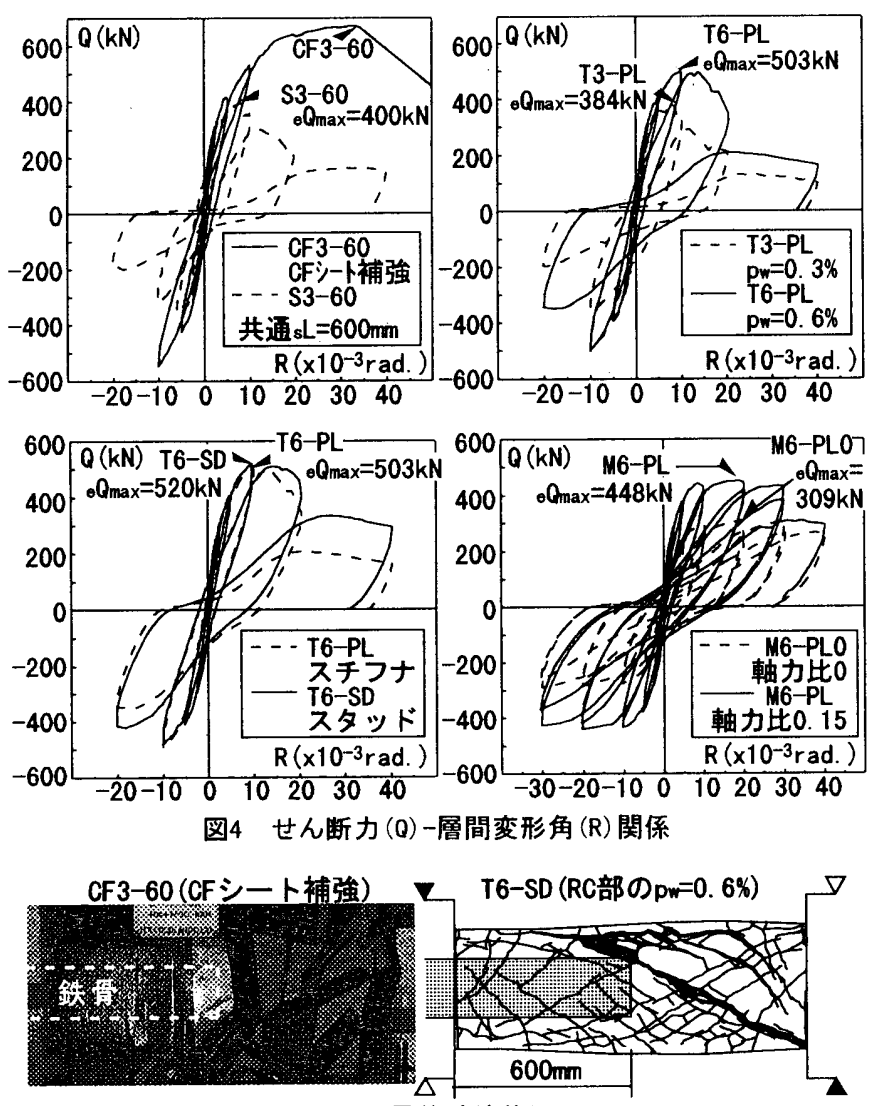

図5最終破填状況

\section{2.2 柱脚部 $S R C$ 造柱頭部 $R C$ 造柱}

図4にせ九断力 $(Q)$-層間変形角 $(R)$ 関係，図5に最終破壊状況の一例 を示古。せ九断破壊先行型の試験体はいずれも主筋降伏の前にせん 断破壊した。曲げ降伏先行型の試験体のうち, 軸力比が 0.150 M6-PLは曲汸降伏後の1/33rad時にせ九断破壊し, 軸力比が0の2 2 試 験体は最終加力時までほとんど耐力低下が無かった。せん断破壊し た試験体はいずれも鉄骨が切断されている位置から柱頭側のRC部 分の破壊が著しかった。 $p w$ が0.3\%のT3-PLに対してRC造区間のみ $p w$ を増やしたT6-PLは耐力の上昇が見られた。また，CFシートでせん 断補強したCF3-60は，S3-60 と比較してせん断耐力が大きく上昇し， $\mathrm{RC}$ 造区間のCFシートの破断と同時に最大耐力となった。また，鉄 骨にスチフナを設けたT6-PLと，スタッドコネクタを設けたT6-SD を比較すると，せん断耐力に関しては大きな差が見られなかった。

図6に，せ九断破壊した試験体の最大耐力実験值を計算值で除し た比較值示寸。ここで，せん断終局耐力計算值は終局強度指針式 A法で算出し，鉄骨の影響は考虑していない。また，CF3-60はせん 断耐力時に計測されたCFシートの歪みが最大で1\%程度であったこ とを考慮し，せん断終局耐力はCFシートの有効応力度を $1 \%$ オず

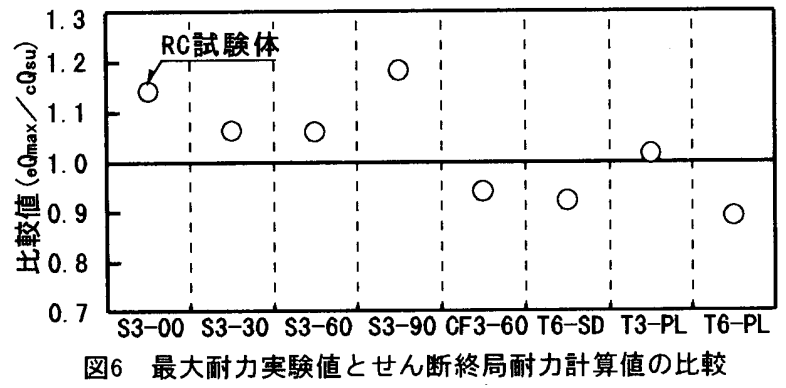

時の灾力上してせえ断補強筋の項㳊算入し計算した。图6によると， CF3-60，T6-SD，T6-PLの3試験体は計算値を下回っていた：また， 鉄骨長さが900mmのS3-90以外は，いずれも鉄骨が無いRC試験体の S3-00よりも比較值が小さくなっていた。このことより，RC部分の せん断補強量を増加させた場合においても，部材の途中まで鉄骨が 存在することによって，RC部分のせん断終局耐力が低下すること が明らかとなった。

\section{3. 部材の終局耐力の算定}

\section{1 RC区間のせん断終局耐力}

既報4)では，部材の一端から鉄骨が延びている部材を対象に，ア 一千機構に伴らコンクリート圧縮束から鉄骨への応力伝達機構を想 定し，材端部に扔ける鉄骨の負担モーメントに応じて，RC区間の コンクリート压縮束の角度が変化するモデルを提案した(図7)。こ のモデルでは, 鉄骨フランジの幅内で直接鉄骨に支圧応力として作 用寸る機構上，伝達筋(せ九断補強筋の一部) 学介し, 鉄骨に伝達さ れる機構が成立寸るとしている。ここで，支圧応力が鉄骨に作用す る範囲はSRC造配筋指針案う)を参考にし $\alpha \cdot s L(\alpha=1 / 3)$ とした。

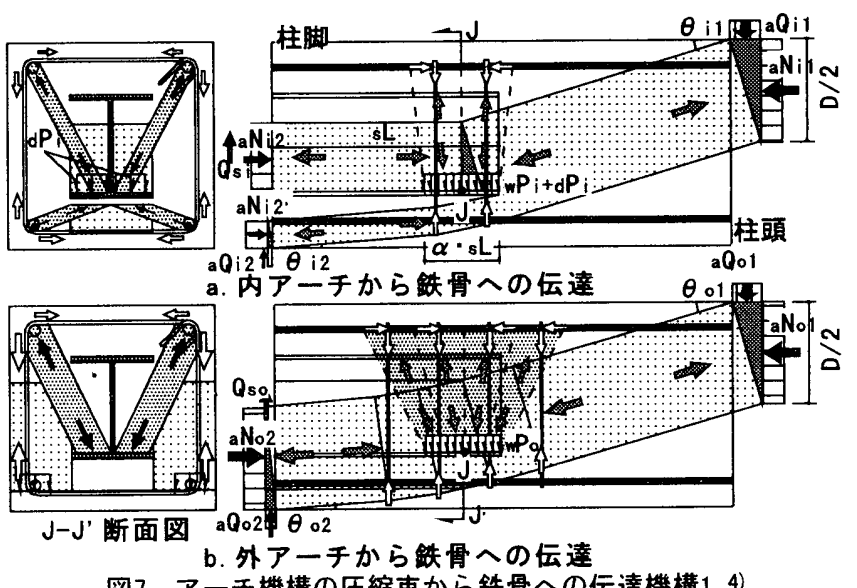

図7 アーチ機構の圧縮束から鉄骨への伝達機構14)

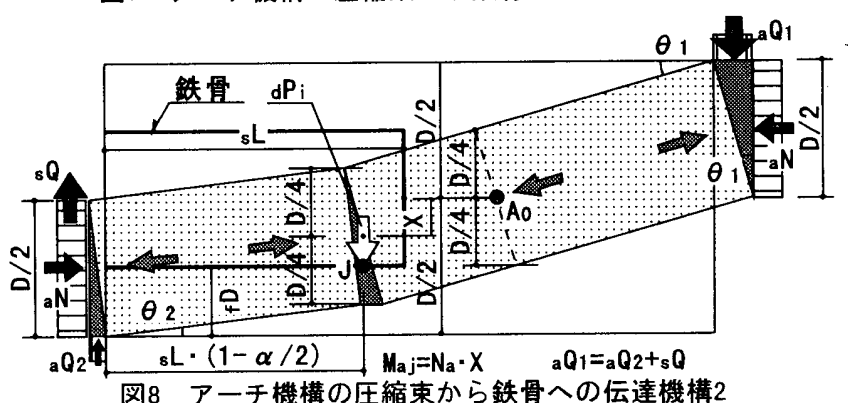

こり支圧応力は便宜上，鉄骨先端から $\alpha \cdot s L / 2$ の点に作用寸る集 中荷重として作用するとし，アーチ機構を形成する外力との釣り合 いを考えると, アーチ機構の圧縮束から鉄骨への伝達機構は図8の ように表される。ここで，この支圧応力が作用する中心点を点と 定義する。この時，点におけるコンクリート圧縮束の部材せい方 向の中心位置を表寸X仿，0からD/4まで変化する。既報4)では，鉄 骨の有効長さ $(s L)$ は，J点から柱脚部までの長さと，アーチ機構が もたらすモーメントの反曲点(A0)から柱脚部までの長さのうちの短 い方としている。一般に，鉄骨が無いRC部材におけるアーチ機構 に伴うコンクリート圧縮束の対称性を考慮すると、柱脚側の材端部 から伸びる鉄骨の長さ $(s L)$ が内法スパンの1/2以下の場合柱，後者に 
よって $s L か ゙$ 定まることはない。本論の提案では $s L$ を式(1)に定める 条件の下で，図8に示した鉄骨切断位置におけるコンクリート玨縮 束の中心の位置を表す $X$ を $D / 4$ とし，せん断終局耐力算定式の簡略 化を図るものである。

$$
s L^{\prime}=\min \left\{s L \cdot(1-\alpha / 2), \frac{1}{2} \cdot L\right\} \quad(\mathrm{mm})
$$

ここで， $s L ：$ 材端部から鉄骨切断位置までの鉄骨長さ $(\mathrm{mm})$,

$a$ : 支圧灾力が作用する区間長さの鉄骨長さに対する比 $(=1 / 3$

5))，L: 部材の内法長さ(mm)である。

図9にXが $D / 4 の$ 時の模式図を示す。この時，コンクリート圧縮束 から鉄骨フランジへ直接作用する部材せい方向の支圧応力 $(d P i)$ によ

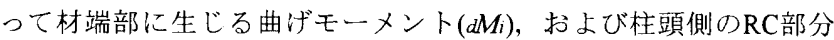
におけるコンクリート圧縮束が材軸方向となす角度 $\left(\theta_{1}\right)$ は，それ ぞれ式(2)および式(3)で表される。

$$
\begin{aligned}
{ }_{d M}= & \left(D+\alpha \cdot{ }_{s} L \cdot \tan \theta{ }_{1}-2 \cdot f D\right) \cdot \frac{a Q_{1} \cdot b_{i}}{D \cdot b} \cdot{ }_{s} L^{\prime} \\
\tan \theta_{1} & =\sqrt{\left(\frac{L-L_{s}^{\prime}}{D}\right)^{2}+1}-\frac{L-{ }_{s} L^{\prime}}{D} \\
{ }_{a} Q_{1} & =\tan \theta_{1} \cdot(1-\beta) \cdot b \cdot D \cdot v \cdot{ }_{c} \sigma_{B} / 2 \\
\beta & =\frac{\left(1+\cot ^{2} \phi\right) \cdot p_{w} \cdot{ }_{w} \sigma_{y}}{\nu \cdot \sigma \sigma_{B}} \\
\nu & =0.7-{ }_{c} \sigma_{B} / 196
\end{aligned}
$$

$(\mathrm{N} \cdot \mathrm{mm}) \quad(2)$

ここで, $D:$ 部材せい $(\mathrm{mm}), f D:$ 鉄骨フランジの部材せい方向 の被り厚 $(\mathrm{mm}), a Q_{1}:$ アーチ機構負担せん断耐力 $(\mathrm{N}), b_{\mathrm{i}}$ : 内ア

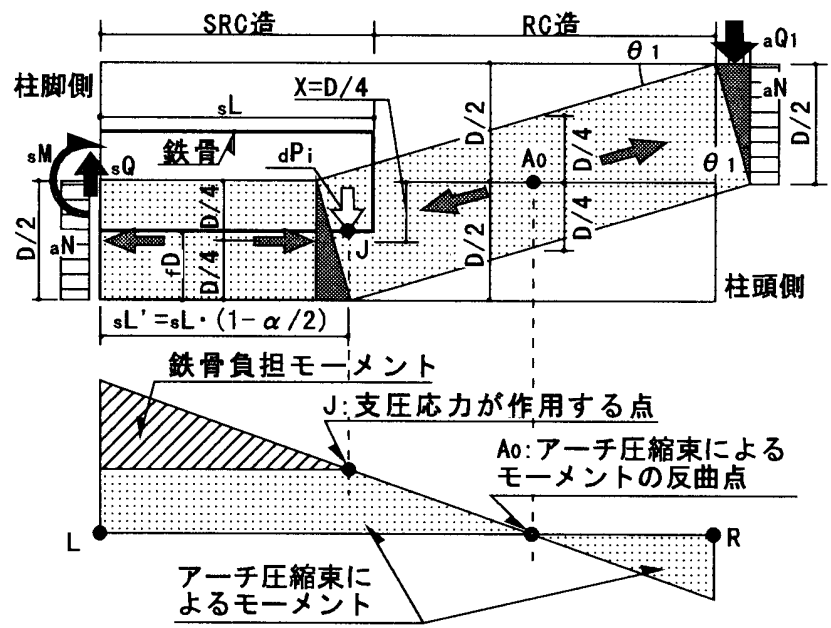

a. 柱脚部SRC造柱頭部RC造の柱

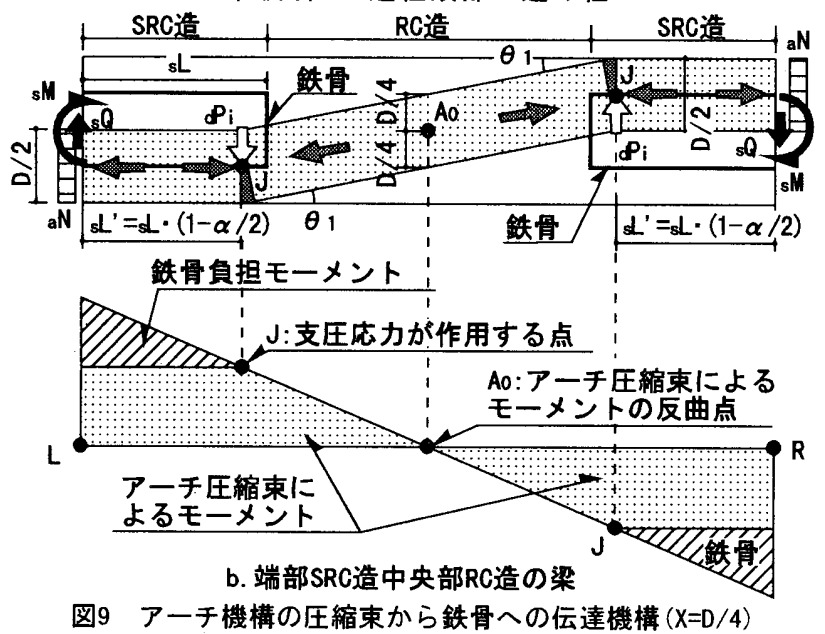

一千機構に伴う圧縮束の幅(=鉄骨フランジ幅 $: \mathrm{mm}), \quad b$ : 部材 幅 $(\mathrm{mm}), \beta$ : コンクリート压繀力のトラス機構の負担比率, $\nu^{\prime}$ : コンクリート压縮強度の有効係数, $c \sigma_{B}$ : コンクリート圧 縮強度 $\left(\mathrm{N} / \mathrm{mm}^{2}\right), \phi$ : トラス機構に伴う圧縮束の材軸に対す る角度( $\mathrm{rad}.), p_{w}: \mathrm{RC}$ 部分のせ九断補強筋比, $w \sigma_{y}$ : 伝達筋*1 (せん断補強筋)の降伏強度 $\left(\mathrm{N} / \mathrm{mm}^{2}\right)$ である。

$(* 1 ：$ 伝達筋とは，鉄骨切断位置付近でRC部と鉄骨間の忘力 伝達に寄与卞るせん断補強筋のこと）

寸なわち，鉄骨の有効長さを式(1)で定め，その条件の下で式(2) および式(3)から，アーチ機構に伴うコンクリート圧縮束から鉄骨 一伝達される曲げモーメントとその圧縮束の角度を算出し, 以下, 既報4)に示した方法によって，RC部分のせん断終局耐力が得られ る。この計算方法を実用せん断終局耐力式之して提案し，式(7)に 示寸。な扔，式を導く過程は既報4)を参照されたい。

$$
\begin{aligned}
& c_{Q u l}= \begin{cases}{ }_{t} Q_{I}+{ }_{a} Q_{I} \cdot \frac{c Q_{d c}}{a Q_{I}+Q_{I}} & \left(c Q_{d c}<a Q_{I}+{ }_{t} Q_{I}\right) \\
{ }_{t} Q_{I}+{ }_{a} Q_{I} & \left(c Q_{d c} \geqq a Q_{I}+{ }_{t} Q_{I}\right)\end{cases} \\
& Q_{I}=\left(b \cdot j_{t} \cdot \cot \phi \cdot p_{w}-\frac{{ }^{n} n \cdot w a}{2}\right) \cdot{ }_{w} \sigma_{y} \\
& { }_{c} Q_{d c}=\frac{c \sigma_{t}-\sigma_{0} \cdot \sin ^{2} \theta}{2 \sin \theta \cdot \cos \theta} \cdot b \cdot D / \kappa \\
& \theta=\min \left\{\tan ^{-1}\left(\frac{j_{t}}{L-s L}\right), \frac{1}{2} \tan ^{-1}\left(-\frac{2 \tau_{p}}{\sigma o}\right)\right\} \\
& \tau_{p}=\sqrt{c \sigma t^{2}-\sigma 0^{*} c \sigma_{t}} \\
& \left(\mathrm{~N} / \mathrm{mm}^{2}\right) \\
& c \sigma=0.313 \sqrt{c \sigma B} \\
& \left(\mathrm{~N} / \mathrm{mm}^{2}\right) \\
& w n=\frac{s M-d M_{i}}{{ }_{s} \cdot \cdot w a \cdot w \sigma_{y}} \\
& s M=\min \left(s M_{p}, \quad s M_{s}\right) \\
& s M_{p}=s Z_{p} \cdot s \sigma y \\
& (\mathrm{~N} \cdot \mathrm{mm})
\end{aligned}
$$

ここで，cQ $Q_{s u l}$ : 鉄骨が途中まで存在する部材のRC部分のせん 断終局耐力 $(\mathrm{N}), c Q d c$ : 斜張力状ひび割れ耐力 $(\mathrm{N}), t Q_{l}:$ トラス 機構負担せ九断耐力 $(\mathrm{N}), \quad j t$ : 主筋中心間距離 $(\mathrm{mm}), c \sigma l: \exists$ ンクリート引張強度 $\left(\mathrm{N} / \mathrm{mm}^{2}\right), \sigma_{0}$ : 軸方向応力度 $\left(\mathrm{N} / \mathrm{mm}^{2}\right)$, $\theta$ : 仮想した斜張力状ひび割れが材軸となす角度 $(\mathrm{rad}),. \kappa$ ： 形状係数（矩形断面：1.5），wn: 鉄骨八の応力伝達化使われ る伝達筋の組数, $w a$ : 一組の伝達筋(せ九断補強筋)の断面積 $\left(\mathrm{mm}^{2}\right), \tau p$ : 斜張力状ひび割れ発生時せ九断応力度 $\left(\mathrm{N} / \mathrm{mm}^{2}\right)$, $s M:$ 材端部において鉄骨が負担する曲げモーメント $(\mathrm{N} \cdot \mathrm{mm})$, $d M i:$ 鉄骨フランジに作用する支圧応力によって材端部に生じ る曲げモーメント $(\mathrm{N} \cdot \mathrm{mm}), s M_{p}$ ：鉄骨の全塑性モーメント $(\mathrm{N}$. $\mathrm{mm}), s M_{s}$ : 鉄骨フランジが受ける支压応力の限界によって定 まるモーメント $(\mathrm{N} \cdot \mathrm{mm}), s Z_{p}$ : 塑性断面係数 $\left(\mathrm{mm}^{3}\right), s \sigma y:$ 鉄 骨降伏強度 $\left(\mathrm{N} / \mathrm{mm}^{2}\right), f t$ : 鉄骨のフランジ厚 $(\mathrm{mm}), r$ : 鉄骨 のフィレット部の半径 $(\mathrm{mm})$ である。

以上は部材の片端だけに鉄骨が存在する場合であるが，このよう にコンクリート圧縮束の位置を簡略化することによって，図9bに示 したような部材の両端部に鉄骨が存在する場合についても，計算式 の適用が可能となる。この場合は，式(10)中のs $L$ を両材端部の鉄骨 長の和，式(3)中の $L^{\prime}$ 在両材端部の有效鉄骨長の和之し，式(1)中の $s L$ おひび $s^{2}$ 在それぞれ片側だけの鉄骨長挹よび有效鉄骨長とするこ とで，中央RC造区間のせん断終局耐力在算出できる。 


\section{2 材端部における曲げ終局䩂力の評価法}

既報2)では，鉄骨が部材の途中で切断されている場合においても， 鉄骨切断位置の曲代補強筋を十分に配し，かつ鉄骨に定着治具を設 汀るこ上によって，鉄骨が材軸方向の引張力を負担し，一般化累加 強度を上回る曲げ終局耐力が材端部で発揮されることが実験により 明らかとなった。一般化累加強度法を用いた断面の曲げ耐力の算定 は，鉄骨，鉄筋およびコンクリートの耐力線をもとに累加を行うた め，内蔵される鉄骨が部材内部で不連続な場合は，断面の曲计耐力 が，鉄骨の負担可能な軸方向力によって制限される。

図1aに示した梁部材では，鉄骨表面とコンクリート間の付着強度 を無視すると，材端部における鉄骨の引張力は，鉄骨に設けたスチ フナあるいはスタッドコネクタ等によって, コンクリートへ伝達さ れると考えられる。つまり鉄骨が負担することが可能な軸方向力は 式(17)上り算出される。

$$
\begin{aligned}
s N= & \min \left\{\left(s N_{I}+{ }_{s} N_{2}\right),{ }_{s} N_{3}\right\} \\
& s N_{I}=0.5 \cdot s d n \cdot s d a \sqrt{c \sigma \sigma_{B} \cdot c E} \\
& N_{2}=p l a \cdot{ }_{c} \sigma_{B} \\
& { }_{s} N_{3}=s a \cdot s \sigma_{y}
\end{aligned}
$$

ここで， $s N_{1}$ :スタッドコネクタのせん断耐力 $(\mathrm{N}), s N_{2}:$ スフナ の支圧耐力 $(\mathrm{N}), s N 3$ :鉄骨の降伏で定まる軸方向耐力, $s d n:$ ス ッドコネクタの本数, $s d a:$ スッドコネクタの軸部断面積 $\left(\mathrm{mm}^{2}\right)$, $c \sigma B:$ コンクリート压縮強度 $\left(\mathrm{N} / \mathrm{mm}^{2}\right), c E:$ コンリート弹性倸 数 $\left(\mathrm{N} / \mathrm{mm}^{2}\right), p l a$ : スチフナ面積 $\left(\mathrm{mm}^{2}\right), s a$ :鉄骨断面積 $\left(\mathrm{mm}^{2}\right)$,

$s \sigma y:$ 鉄骨降伏強度 $\left(\mathrm{N} / \mathrm{mm}^{2}\right)$ である。

式(18)は各種合成構造設計指針・同解説10)によるスタッドコネク タのせん断耐力, 式(19)は鉄骨に設けたスチフナのコンクリートに 対する支压耐力であり，これらの和を鉄骨の定着耐力としている。

図10に鉄骨の軸方向耐力をその定着耐力で制限し，一般化累加強 度法によって算出したSRC断面の $N-M$ 相関曲線を示す。ここで計算 に使用した断面は, T形断面のXT-WEの材端部と, 柱試験体のM6PLそM6-PL0の柱脚部である。これによると，部材に載荷される圧 縮軸力が小さいところから引張軸力の範囲と圧縮軸力が極めて大き い範囲で，SRC断面の曲げ終局耐力が低下寸る領域がある。圧縮軸 力が極めて大きい所は軸力比が約 0.8 以上であり, 通常の部材では 想定しない軸力比の領域であるが，圧縮軸力が小さい方の領域には， 軸力比が零である梁部材が含まれる可能性がある。特にT形断面の XT-WEでは上端圧縮（スラブ圧縮）と下端圧縮（スラブ引張）で

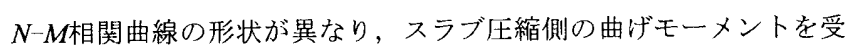
ける場合に，曲げ終局耐力が低下する領域が大きくなっていた。一

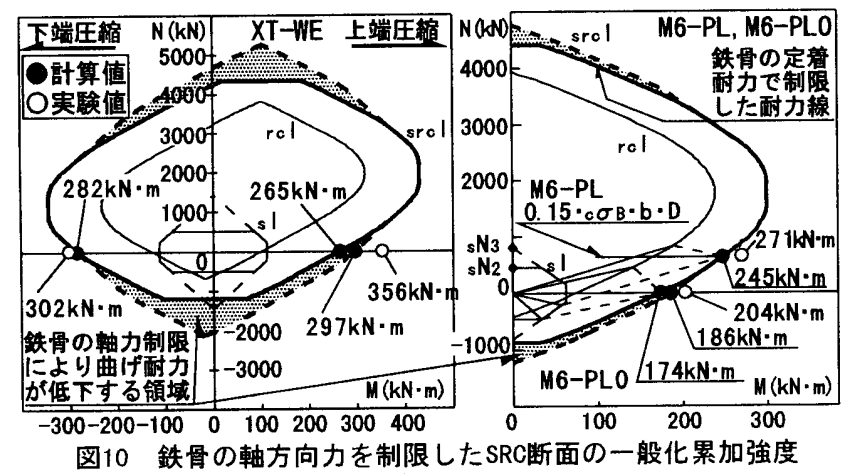

方, 軸力比が0.15であるM6-PL注, 単純累加強度上一般化累加強度 の耐力差がほとんよ゙ない領域であるため，鉄骨が負担可能な軸方向 カによる影響はみられなかった。

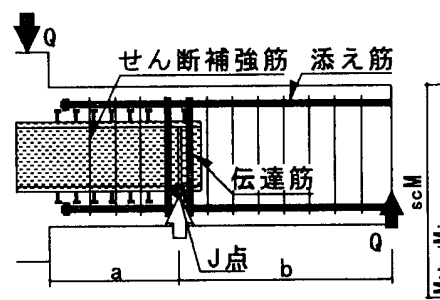

a. 固定端SC造自由端RC造の部材

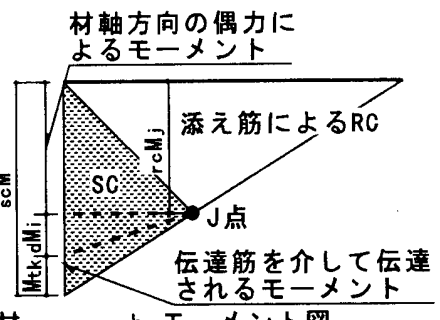
b. モーメント図 図11 鉄骨が途中で切断されている片持ち梁

\section{3. $3 \mathrm{SRC}$ 造からRC造への切り替え部の曲げ補強}

図11に固定端側が鉄骨コンクリート(以下SC)造, 自由端側がRC 造の片持ち梁とそのモーメント図を示寸。モーメント勾配の途中で 鉄骨が切断されている上きは，鉄骨が存在しない区間の曲汭モーメ ントを負担するために，材軸方向の鉄筋が必要である。この鉄筋を 添え筋と呼ぶ。鉄骨が曲げモーメントを頁担し始める点をJ点とす ると, J点でRC部の曲壮モーメントが最も大きくなると予想される。 J点を通る断面の曲げモーメント r M M

$$
{ }_{r c} M j=\frac{b}{a+b} \cdot s c M \quad(\mathrm{~N} \cdot \mathrm{mm})
$$

ここで, $a: \mathrm{J}$ 点から固定端までの長さ $(\mathrm{mm}), b: \mathrm{J}$ 点から自由端 までの長さ $(\mathrm{mm}), s c M$ : 固定端側 $\mathrm{SC}$ 造断面の曲げモーメント $(\mathrm{N}$ ·mm)である。

鉄骨に定着治具等を設けた場合，材端部の鉄骨はSC断面として 曲げモーメントを負担するため，鉄骨の全塑性モーメントよりも曲 げ終局耐力が大きくなる。この場合はSC断面としての曲价終局耐 力を一般化累加強度法等により算出し，それに応じて添え筋による 曲げ補強筋を増やす必要がある。

既往の研究6),7)では式(21)から算出される切り替え部の曲げモー メントに対して，ある余裕率を乗じて切り替え部に曲げ補強を施す ことで，材端部に降伏ヒンジが形成されると報告されている。この 余裕率には，材端部の鉄骨のひずみ硬化や降伏域の伸展による曲げ 耐力の上昇などの影響も考慮されていると思われる。

一方で，切り替え部付近の添え筋に生じる応力に対して, 添え筋 がSC造の区間に確実に定着されることが重要である。それによっ て材軸方向の偶力による曲げモーメントの伝達が可能となり, J点 を通る断面で負担していた曲げモーメントが固定端側のSC造部分 に伝達される。

$\mathrm{RC}$ 部から $\mathrm{SC}$ 部への応力伝達機構は, 材軸方向の添え筋等を介し た偶力によるもの，伝達筋を介して鉄骨フランジに作用する材軸と 直交方向の支圧応力によるもの，拉よび図7aに示したアーチ機構に 伴うコンクリート圧縮束から直接鉄骨フランジに作用するもの $(d P i)$ が考えられる。ここで，伝達筋による応力伝達を考えると，鉄骨切 断位置付近に配される伝達筋はJ点の近傍に集中的に配される方が 効果的である。しかし, 施工上の理由からこの伝達筋をある範囲に 分散させて配筋する方法が考えられ，SRC造配筋指針案5)では，鉄 骨フランジが支圧応力を受ける範围から両側45度の範囲に含まれる せ九断補強筋を伝達筋と考えるとしている。この時の切り替え部付 


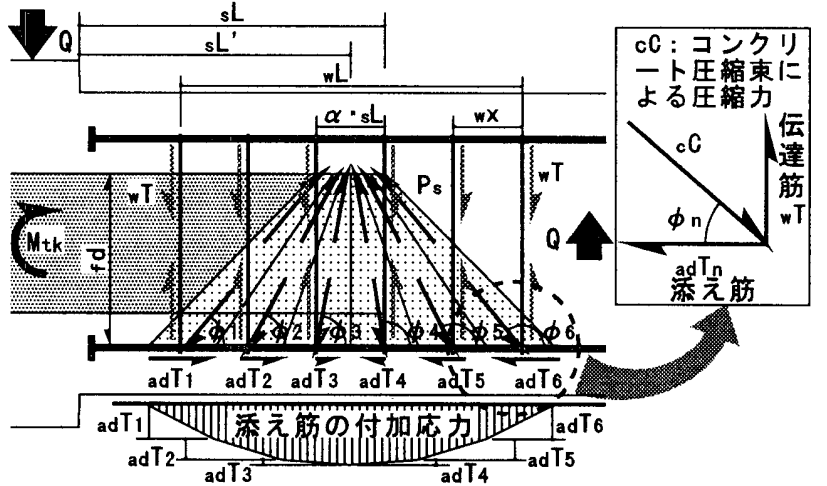

図12 伝達筋を介して鉄骨に作用する支压応カとその釣り合い 近の力の鈎り合いを図12に示す。

図11に示した梁に扔いて，材端部のSC部が負担する曲げモ一メ ント $(s c M)$ のち伝達筋を介して伝達される曲代モーメント $(M t k)$ は， 式(22)で表される。

$$
M_{t k}={ }_{s c M}-{ }_{r c M j}-{ }_{d} M_{i} \quad(\mathrm{~N} \cdot \mathrm{mm})
$$

ここで，dMi：図9に示したアーチ圧縮束から直接鉄骨に作用す る支压応力 $(d P i)$ によって伝達される曲げモーメント[式(2)] $(\mathrm{N} \cdot \mathrm{mm})$ である。

必要な伝達筋の組数を算出する場合は，アーチ圧縮束によって伝 達される曲げモーメント $d M i を$ 無視して，その分をすべて伝達筋を 介して伝達されるとしても良い。これは切り替え部の曲げ補強量を 計算寸る上でも安全側の略算となる。また, 添え筋を介した材軸方 向の偶力による応力伝達が無い場合は式(22)のrcMjは零となる。こ の時に必要とされる伝達筋の組数 ( $(w n)$ は, SRC造配筋指針案5)に示 されている方法により算出される。つまり，伝達筋を介して鉄骨に 作用する支圧応力が点に作用すると考えると，支圧応力 $P_{s} ，$ 打よ びその時に必要な伝達筋の組数wnはそれぞれ式(23), および式(24) から算出される。

$$
\begin{aligned}
& P_{s}=\frac{M i k}{s L \cdot(1-\alpha / 2)} \\
& { }_{w n}=\frac{P_{s}}{w Q \cdot \sigma_{y}}
\end{aligned}
$$$$
\text { (N) }
$$

図12において，引張側の添え筋と支圧応力を受けるフランジまで の長さを $f$ とする。また，端から $n$ 番目の伝達筋が形成するコンク リート圧縮束が材軸方向之なす角度 $\left(\phi_{n}\right)$ は式(25)で表される。

$$
\begin{aligned}
\tan \phi_{n} & =\frac{f d}{w L-2(n-1) \cdot w x} \\
w x & =\frac{w L}{w n-1}
\end{aligned}
$$$$
(\mathrm{mm})
$$

ただし, $\left|\tan \phi_{n}\right| \geqq 1$ とする。

ここで，伝達筋の間隔 $(w x)$ は， $w n$ 組の伝達筋をJ点を中心とする wLの範囲に均等に配されているものとする。

前述の通り，フランジが支圧応力を受ける位置から左右 $45^{\circ}$ の範 囲のせん断補強筋を伝達筋として有効であると考えると， $\tan \phi n$ 汪 1以上とする必要がある。図12に示す釣り合いを成立させるために は，端から $n$ 番目の伝達筋によって $a d T_{n}$ の引張応力が添え筋に生じ る。wLの区間に含まれる最端部から点までの伝達筋の引張応力と 釣り合うために，添え筋に生じる引張応力の合計 $\Sigma_{a d T}$ 式(27)より
算出される。

$$
\begin{aligned}
\sum_{a d} T & =\sum_{n=1}^{k}\left(\frac{w L-2 \cdot(n-1) \cdot w x}{2 \cdot f d}\right) \cdot{ }_{w} T \\
& w T=w a \cdot{ }_{w} \sigma_{y} \\
k & =\operatorname{int}(w n / 2)
\end{aligned}
$$

ここで, $\operatorname{int}(X): X$ を超えない最大の整数を表す関数である。

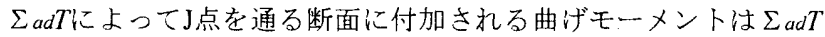
•fdである。よって図11において，材端部の曲计終局耐力時に鉄骨 切断位置のRC断面を曲计降伏させないためには，式(30)を満たす添 え筋を配寸る必要がある。

$$
\eta \cdot\left(\frac{b}{a+b} \cdot{ }_{s c} M+\Sigma_{a d} T \cdot f d\right)<0.9 \cdot{ }_{a d} a \cdot a d \sigma y \cdot d
$$

ここで， ク：曲げ設計用余裕率 $(\geqq 1), a d a ：$ 添え筋断面積 $\left(\mathrm{mm}^{2}\right)$, ad $\sigma_{y}$ : 添え筋降伏強度 $\left(\mathrm{N} / \mathrm{mm}^{2}\right), d$ : 有効部材せい(mm)である。

式(30)の左辺は材端部の曲壮終局耐力時に鉄骨切断位置に生じる

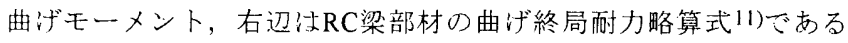
ここで，右辺の曲计終局耐力の算定は他の計算方法によることも可 能である。実際には，部材の全長に渡って主筋が通っているため， 主筋による曲计耐力の增加も考虑に入れる必要がある。

鉄骨を含んだ断面の曲代終局耐力 $s c M$ M一般化累加強度法により 算出することができるが，一般的に曲价破壊するSRC部材の最大耐 力は変形の増大と共に大きくなり, 最大耐力を一般化累加強度法に よる計算值で除した値の平均は1.2～1.3となるとされている11)。ま た， RC断面の曲げ耐力を表す右辺の式では同じく1.1〜1.2程度にな るとされている11)。のようにRC造とSRC造では，断面の曲げ耐 力を算定古る計算式の安全率が異なるので， クの值は1.1〜1.2程度 とすることが望ましい。

図13に端部SRC造中央部RC造梁の各試験体の実験経過を示す。 部材の曲げ降伏後にせん断破壊した試験体，およざ添え筋が定着破 壊した試験体では，その最大耐力の直後または直前に切り替え部を 通る断面の主筋が降伏していた。これは肋筋の降伏，あるいは材軸 方向の添え筋等を介した偶力による応力伝達機構の襄失等の原因に より, 応力伝達機構の均衡が変化し, その結果, 切り替え部付近の 主筋が降伏したものと推測される。一方で，最終加力時まで，耐力 低下が生じなかったX-WEとX33-PLでは切り替え部付近の主筋は降 伏しなかった。T形断面のXT-WEは，上端圧縮時にスラブコンクリ 一トの影響でSRC断面としての材端モーメントが大きくなるため, 切り替え部において主筋が降伏したものと思われる。

切り替え部付近の添え筋および主筋は，材軸方向の忍力伝達に関 しても重要な役割を担っている。特に梁部材において, 曲师降伏後 の勒性能を確保するためには，材端部の曲代耐力の増加や降伏域の

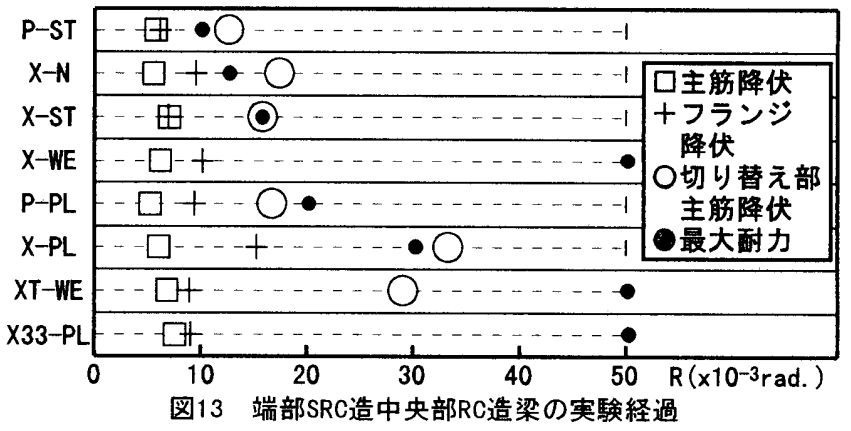


伸展等を考慮して, 鉄骨切断位置には余裕を持たせた曲汸補強を施 寸必要がある。

\section{4. 最大酎力実験値と提案式計算値の比較}

3.1節および3.2節に示した，部材の途中まで鉄骨が存在する部材 における，RC部分のせん断終局耐力，およびSRC断面にお打る曲 げ終局耐力の計算法によって，表1および表2に示した一連の部材実 験の結果を評価する。

図14は縌軸に最大耐力実験値を曲价終局耐力時せん断力計算值で 除した值，横軸にせん断終局耐力計算值を曲代終局耐力時せん断力 計算值で除したせん断余裕度をとり，各実駼值をプロットしたもの である。ここで，曲壮終局耐力時せん断力の計算值は両材端部の曲 壮終局時モーメントを部材の内法スパン長で除した值とした。また， 中央RC部にX形筋を使用している試験体においては，X形筋による せん断補強効果は引張側となる鉄筋のみを算入し，その時に用いた 鉄笳の有効引張応力度は， $\mathrm{SRC}$ 部分に定着されている鉄筋の付着強 度とプレート定着の定着強度の和から算定される応力度とし，X形 筋の端部が鉄骨フランジに溶接されている場合は舟材の降伏強度を 有効引張応力度とした2)。

破壊状況別に見ると，曲げ降伏以前にせん断破壊した試験体は， いずれも計算值と良い対応をしており，最大耐力実駼值をせん断耐 力計算値で除した值は，1.14から1.25であった。また，曲げ破壊し 最終加力時までほとんど耐力低下がなかった試験体は，最大耐力実 験值を曲げ終局耐力時せん断力で除した值は，1.13〜1.20であった。 さらに，曲汭降伏後にせん断破壊した試験体は，せん断余裕度が 0.98〜1.17であった。

これらをグラフ上で見ると，実験要因による偏りやばらつきも見 られず，3.1節に示した実用せん断終局耐力式によって算出される せん断終局耐力計算值，および3. 2節に示した鉄骨が負担可能な軸 方向耐力によって制限される一般化累加強度法による曲げ終局耐力 は，実験から得られた最大耐力を良く評価していた。また，計算か ら得られたせん断余裕度によって破壊形式の分類をすることが可能 であった。

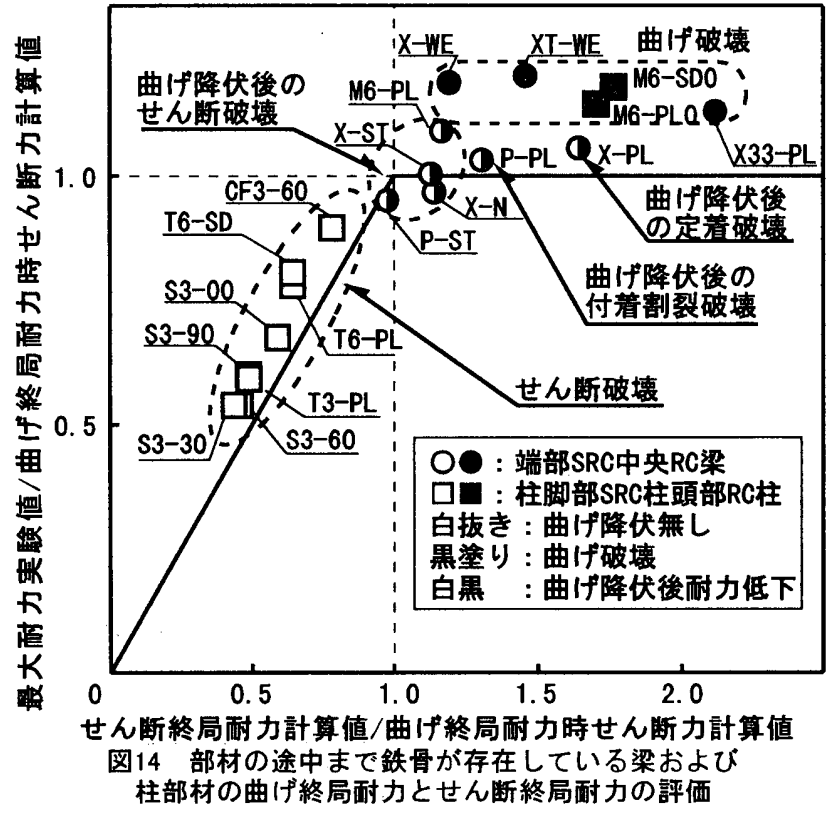

\section{5. 結論}

部材の途中まで鉄骨が存在する部材を対象上した一-連の実験を基 に，構造形式が切り替わる箇所にお打る応力伝達機構と部材の終局 耐力に関主る考察を行い，以下に示寸知見を得た。

(1)既報3)4)に引き続き，柱脚部から延びる鉄骨が柱高さの半分まで 存在する柱の曲げせん断実験を行った結果， RC部分のせん断補 強量を增加させた場合においても，せん断終局耐力が低下し，既 往の計算式ではせん断終局耐力を危険側に評価寸る可能性がある こ上が明らかとなった。この耐力低下は既報4)で指摘したように， 内藏される鉄骨によるせん断抵抗機構の変化に起因していると考 えられる。

(2)部材の途中まで鉄骨が存在するコンクリート系部材のRC部分の せ九断終局耐力算定式として，鉄骨切断位置に作用するア一チ機 構に伴うコンクリート圧縮束の位置を簡略化した計算式を提案し た。この提案式による計算值は，一連の柱実験においてせん断破 壊した試験体の最大耐力を，偏り無く安全側に評価した。

(3)部材の途中で切断された鉄骨を含んだSRC断面の曲げ終局耐力 は，その鉄骨の定着耐力を考慮した一般化糸加強度で安全側に評 価することができた。本論で提案したRC部分のせん断終局耐力 算定式と併せることによって，本研究で赛施した試験体の最大耐 力を推定し，破壊モードを分類することが可能であった。

(4)SRC造からRC造へと切り替わる箇所において，材軸之直交方向 に配された伝達筋を介して応力伝達機構が形成されるとき，鉄骨 切断位置に配される材軸方向の添え筋には，鉄骨切断位置の曲汭 モーメントの分担の他に, 材軸方向の引張応力が付加されること を指摘し，その評価法を提案した。

\section{謝辞}

本研究をまとめるにあたり，福山大学工学部南宏一教授に貴重な 御助言を賜りました。ここに感謝の意を表します。

\section{参考文献}

1)鈴木英之, 西原 寬, 松㥓育弘 : SRC造からRC造、構造形式が切り替わる柱のせん断 性状，日本建築学会大会学術請演梗概集，C-1，pp.1069-1070，1999.9

2)鈴木英之，西原寞，松本智夫，田畑 卓南宏一: 端部 $S R C$ 造中央部RC造て構成 される複合梁の構造性能，構造工学論文集，Vol.44B，pp.181-190，1998.3 3)鈴木英之，西原 竟，松崎育弘：柱高さの途中まで存在する鉄骨がRC柱のせん断性状 に及ぼ寸影響，コンクリート工学年次論文報告集，Vol.21，No.3，pp.577-582， 1999.7

4鈴木英之，西原 寛，松崎育弘：SRC造からRC造一構造形式が切り替わる柱のせん断 耐力の評価，日本建築学会構造系論文集、第525号, pp.125-132，1999.11

5) 日本建築学会 : 鉄骨鉄筋コンクリート造配箭指針案)・同解説，1994.7

6)岩田昌之，太田道产他 : 端部SRC・中央部RCをする合成構造梁の実験的研究(その1〜 5), 日本建築学会大会学術講演梗概集C，(その1)pp.1329-1330，1987.10，(その2〜 3)pp.1439-1442, 1988.10, (その4 5)pp.1445-1448, 1989.10

7)福知保長，外狩吉隆：SRC-RC梁の接䄯部に関する実駼的研究，コンクリート工学年次 論文報告集，Vol.10，No.3，pp.201-204，1988.6

8)林村膶一，新宮義信：繰返しせん断曲げを受けるSRC-RC混合柱材の構造性能，日本 建筑学会九州支部咞究報告, 第37号, pp.505-508，1998.3

9)西村泰志，岡本昌泰，馬場望：RC部材とSRC部材が直列的侸結合される接合部の応力 伝達その2 3, その5), 日本建筑学会大会学術满演㤦概集C-1，(その2〜3), pp.10631066, 1999.9, (その5)pp.1265-1266, 2000.9

10)日本建築学会 : 各種合成構造設計指針・同解哾 1985

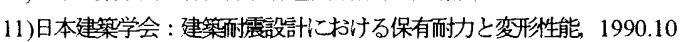

（2001年 3 月 7 日原稿受理， 2001 年 7 月 5 日採用決定） 